Supplementary Information

\title{
Thermodynamic dissection of potency and selectivity of cytosolic Hsp90 inhibitors
}

Chihoko Yoshimura, ${ }^{1}$ Satoru Nagatoishi, ${ }^{2}$ Daisuke Kuroda,${ }^{3}$ Yasuo Kodama,${ }^{1}$

Takao Uno, ${ }^{1}$ Makoto Kitade, ${ }^{4}$ Khoontee Chong-Takata, ${ }^{1}$ Hiromi Oshiumi, ${ }^{5}$ Hiromi

Muraoka, ${ }^{1}$ Satoshi Yamashita, ${ }^{1}$ Yuichi Kawai, ${ }^{1}$ Shuichi Ohkubo, ${ }^{1}$ Kouhei

Tsumoto $^{2,3 *}$

${ }^{1}$ Discovery and Preclinical Research Division, Taiho Pharmaceutical Co. Ltd., Tsukuba, Ibaraki 300-2611, Japan

2 The Institute of Medical Science, The University of Tokyo, 4-6-1 Shirokanedai, Minato-ku, Tokyo 108-8639, Japan.

${ }^{3}$ Department of Bioengineering, Graduate School of Engineering, The University of Tokyo, 7-31 Hongo, Bunkyo-ku, Tokyo 113-8656, Japan.

4 Chemical Technology Laboratory, CMC Division, Taiho Pharmaceutical Co. Ltd., Kamikawamachi, Kodama-gun, Saitama 367-0241, Japan

5 Formulation Research, CMC Division, Taiho Pharmaceutical Co. Ltd., Kawauchi-cho, Tokushima 771-0194, Japan 


\section{Table of Contents}

Figure S1. Chemical structures of TAS-116 analogs and known Hsp90 inhibitors......S3

Figure S2. Binding analyses of compounds to Hsp90 performed using SPR.........S4

Figure S3. Competitive binding assay of inhibitors by using fluorescence polarization. S5

Figure S4. Competitive binding titration of 17-AAG into human Hsp90 $\alpha$ NTD pre-bound

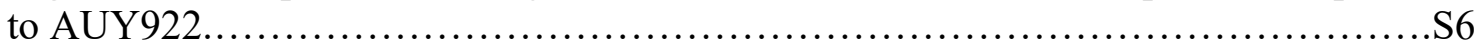

Figure S5. Molecular model of THS-510 (cyan) bound to human Hsp90. A) contact residues (stick model) in Hsp90 with THS-510 calculated by PISA Server. binding results aligned with B) BIIB021 (green) and C) AUY922 (magenta).......................S7

Figure S6. ITC profiles of THS-510 and TSA-116 bindings at different temperatures...S8

Figure S7. Overlay of the structure of human Hsp90 $\alpha$ in complex with TH-828 with that of human Grp94 in complex with PU-H54 (PDB: 3O2F) .......................... 9

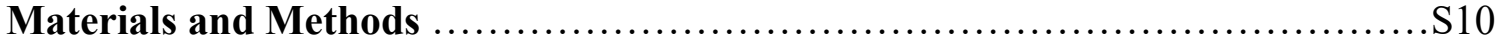


(A)

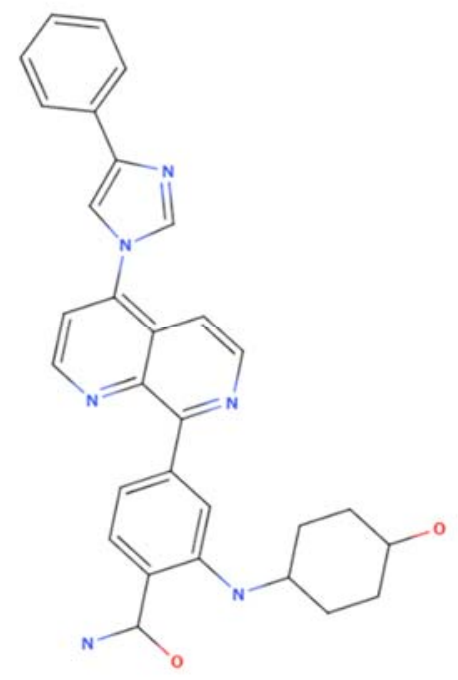

THS-828

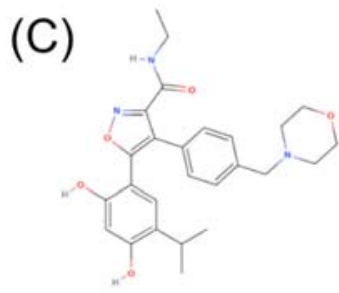

AUY-922
(D)

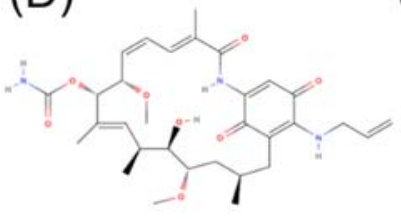

17-AAG
(B)

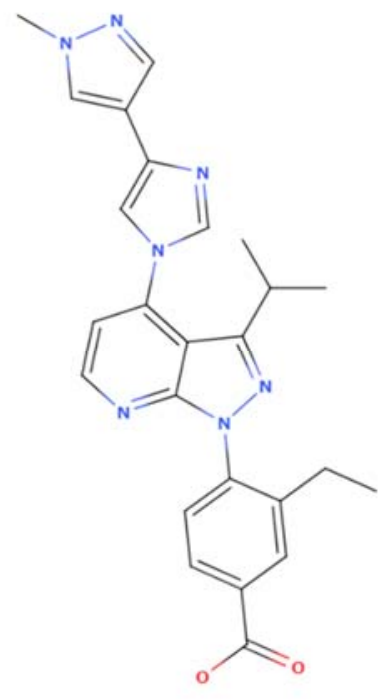

THS-2415

(E)

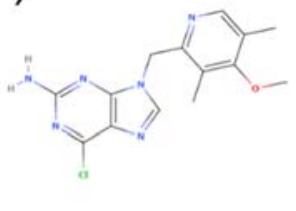

BIIB-021
(F)

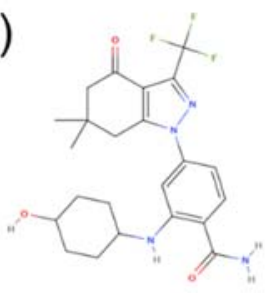

SNX-2112

Figure S1. Chemical structures of TAS-116 analogs and known Hsp90 inhibitors (A) THS828, (B) THS-2415, (C) AUY922 (type 1 inhibitor), (D) 17-AAG (type 1 inhibitor), (E) BIIB021 (type 2 inhibitor), and (F) SNX-2112 (type 2 inhibitor). 

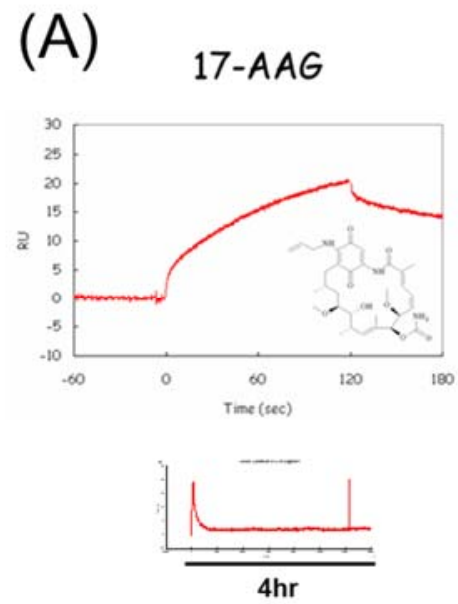

(B)
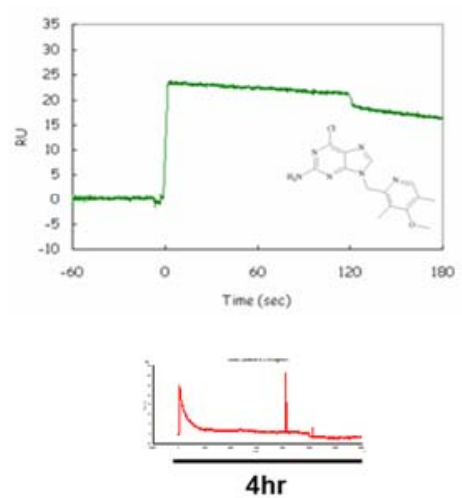

(C) SNX-2112
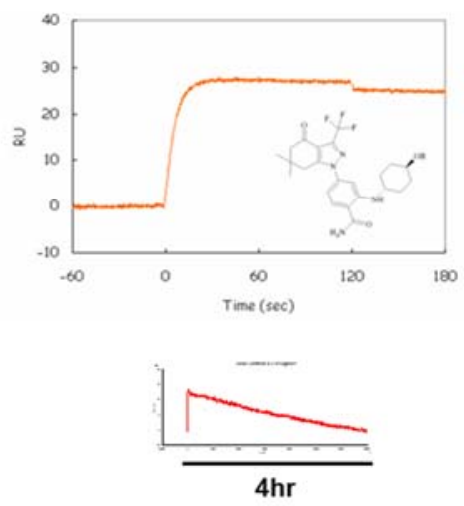

Figure S2. Binding analyses of compounds to Hsp90 performed using SPR (A) 17-AAG, (B) BIIB021, and (C) SNX-2112. SPR profiles of the inhibitors (Upper). The dissociation responses of the inhibitors (Lower). 

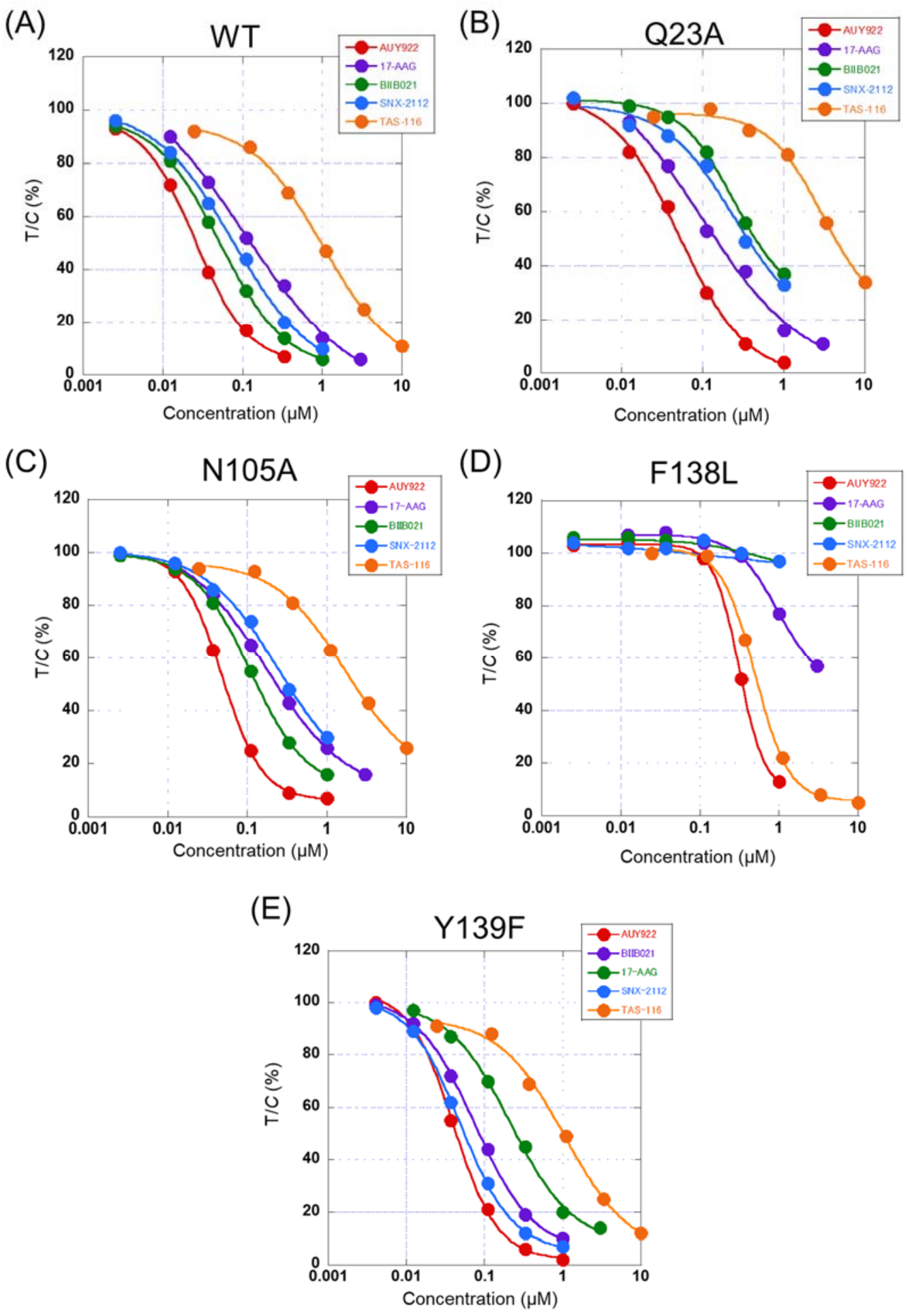

Figure S3. Competitive binding assay of inhibitors by using fluorescence polarization. Plotted is the percent ratio of the intensity of the test and control lines versus concentration of inhibitor. (A) WT, (B) Q23A (C) N105A, (D) F138L, and (E) Y139F. 


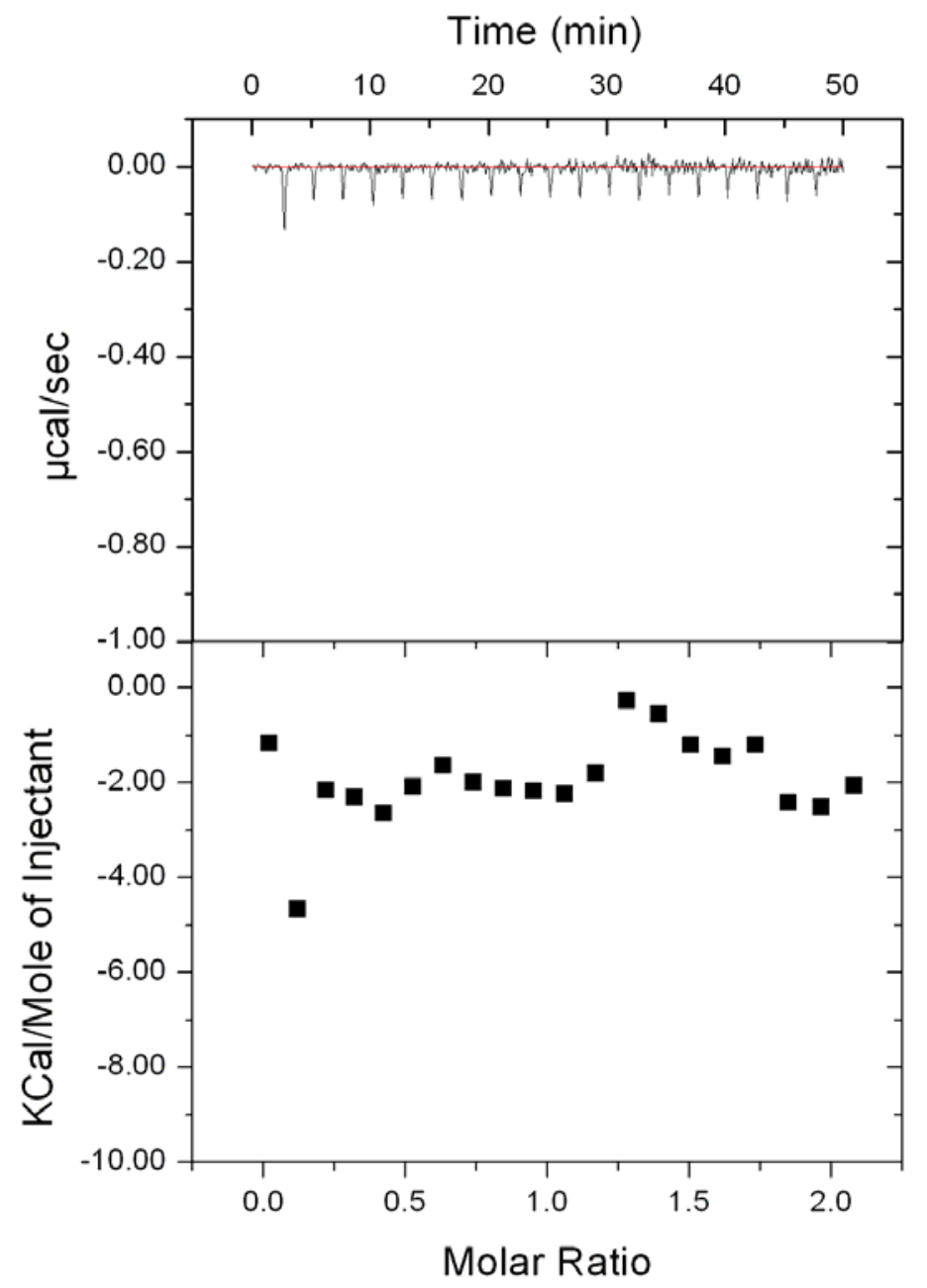

Figure S4. Competitive binding titration of 17-AAG into human Hsp90a NTD pre-bound to AUY922. 

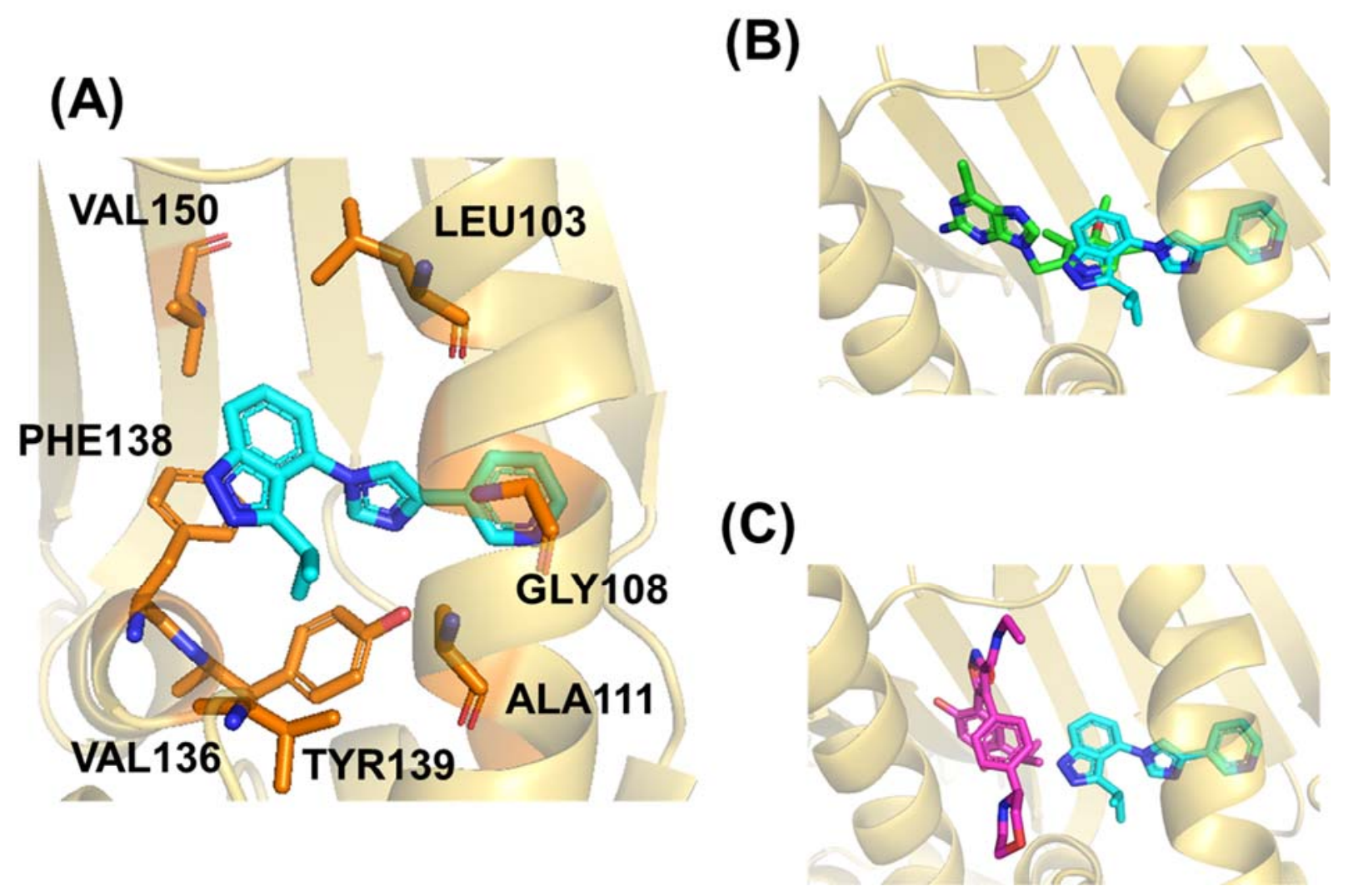

Figure S5. Molecular model of THS-510 (cyan) bound to human Hsp90. A) contact residues (stick model) in Hsp90 with THS-510 calculated by PISA Server. binding results aligned with B) BIIB021 (green) and C) AUY922 (magenta). A ribbon diagram of the protein is shown. The inhibitors are shown as ball-and-stick renderings. 

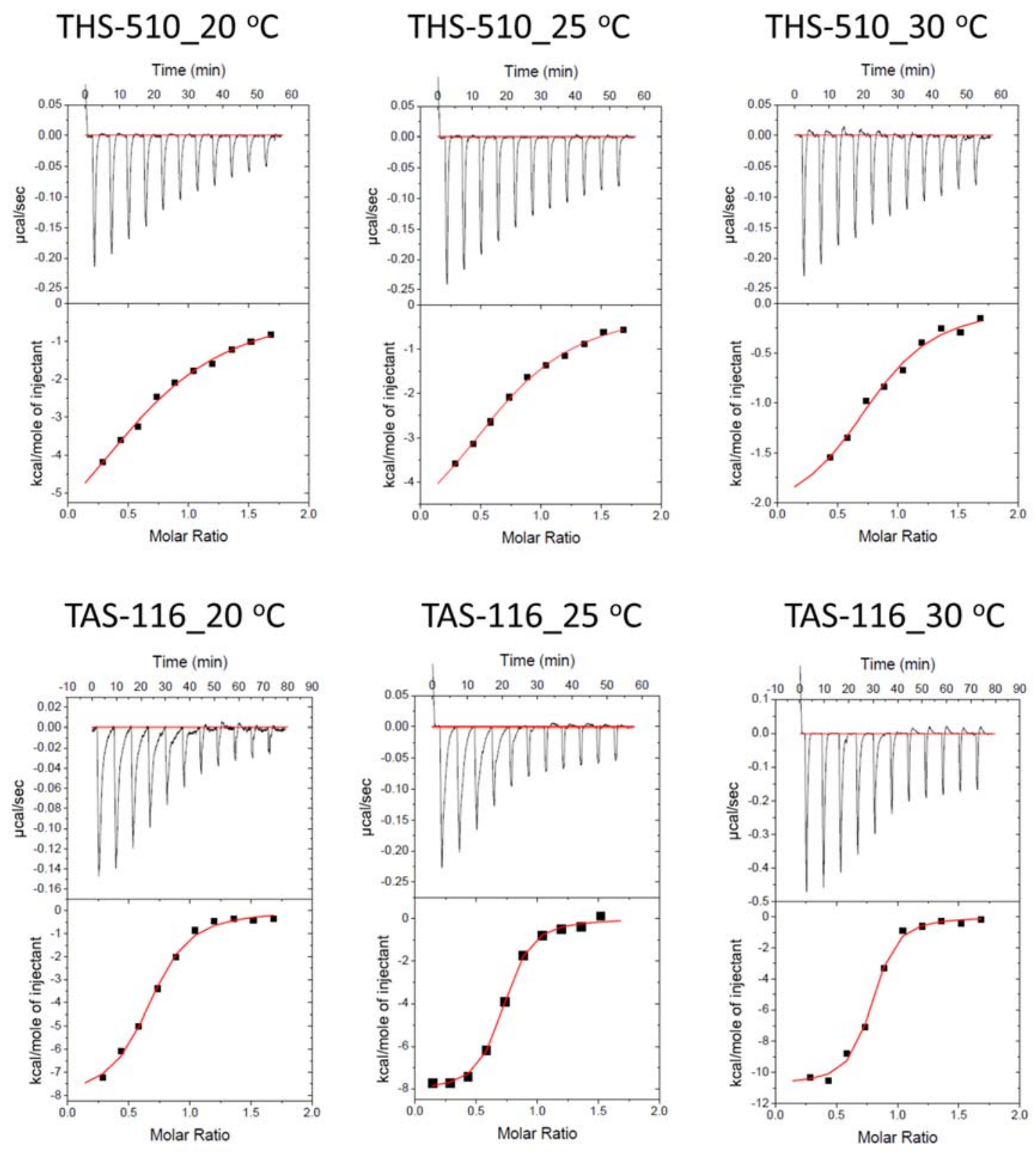

Figure S6. ITC profiles of THS-510 and TSA-116 bindings at different temperatures 

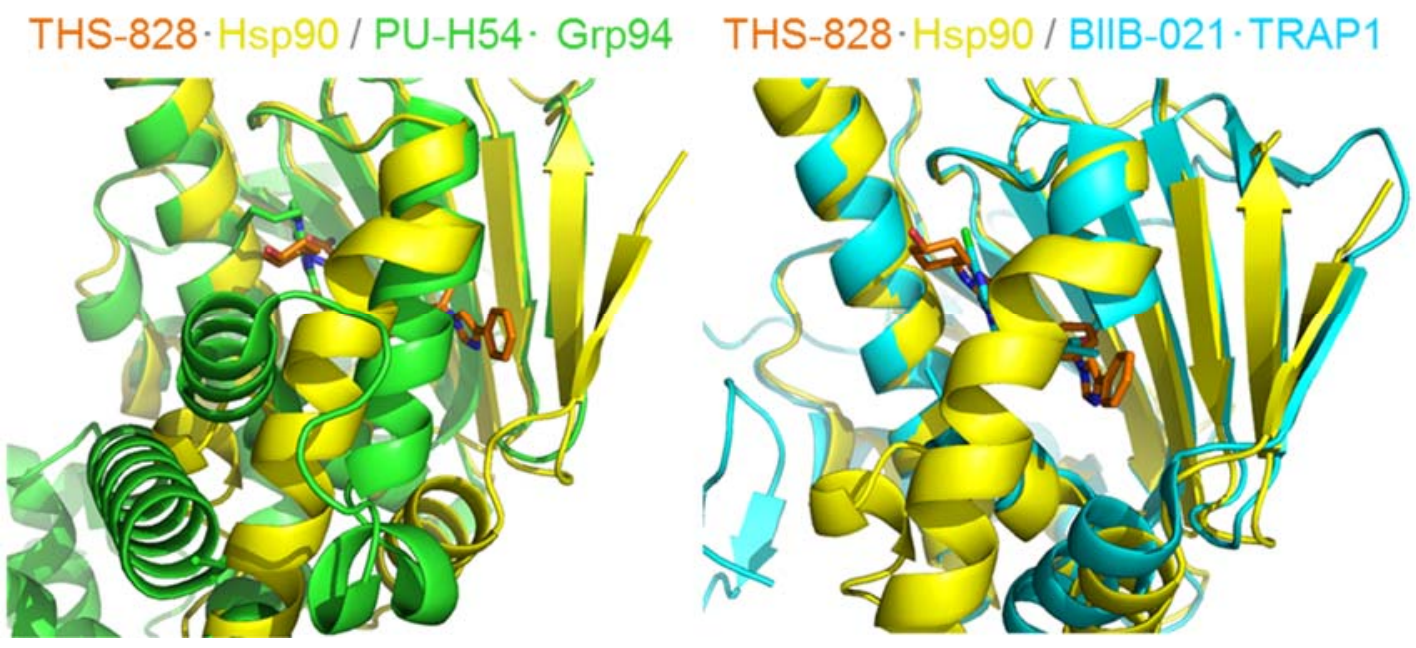

Figure S7. Overlay of the structure of human Hsp90a in complex with TH-828 with that of human Grp94 in complex with PU-H54 (PDB: 3O2F) (left) and of human Hsp90a in complex with TH-828 with that of human TRAP1 in complex with BIIB021 (PDB: 4Z1G) (right). Human Hsp90a is shown in yellow, human Grp94 is shown in green, and human TRAP1 is shown in cyan. Inhibitors are shown in ball-and-stick renderings; THS-828 is in orange. 


\section{Materials and Methods}

\section{EXPERIMENTAL SECTION}

Chemicals. TAS-116, THS-828, THS-510, THS-762, and THS-975 were synthetized at Taiho Pharmaceutical Co., Ltd. as previously described. ${ }^{1,2,3}$

General chemistry information. All solvents and reagents were obtained from commercial sources and used as received. Flash chromatography purifications were performed using Isolera ${ }^{\mathrm{TM}}$ One flash purification systems from Biotage Inc. with a prepacked Biotage ${ }^{\circledR}$ SNAP Ultra column (25 $\mu \mathrm{m}$, spherical particles), Biotage ${ }^{\circledR}$ Sfär Silica HC D column $(20 \mu \mathrm{m}$, spherical particles), or Biotage $^{\circledR}$ Sfär KP-Amino D column $(50 \mu \mathrm{m}$, spherical particles). All the synthetic compounds were assessed using ultra-performance liquid chromatography-mass spectrometry (UPLC-MS). UPLC-MS analysis was performed using an ACQUITYTM UPLC system (Waters Corporation, Milford, MA, USA) and a Micromass ZQ Mass Spectrometer (Waters Corporation, Milford, MA, USA) equipped with electrospray ionization in the ESI positive mode. The column used was an Acquity UPLC ${ }^{\circledR}$ BEH C18-column $(2.1 \mathrm{~mm} \times 50 \mathrm{~mm}, 1.7 \mu \mathrm{m}$, Waters Corporation $)$ at $40^{\circ} \mathrm{C}$ with a flow rate of $0.5 \mathrm{~mL} / \mathrm{min}$. Mobile phase A was $0.5 \%$ formic acid in water. Mobile phase B was $0.5 \%$ formic acid in acetonitrile, which increased linearly from $5 \%$ to $95 \%$ over 2 min and $95 \%$ to $98 \%$ over the next $1.4 \mathrm{~min}$, after which the column was equilibrated to $5 \%$ for $1.5 \mathrm{~min}$ and detection was conducted at $254 \mathrm{~nm}$. All the final test compounds were purified to $\geq 95 \%$ chemical purity, as measured using UPLC-MS. The proton nuclear magnetic resonance (1H NMR) spectra were recorded on a Varian Mercury-400 (400 MHz), JEOL JNM-AL400 (400 MHz), BRUKER AVANCE NEO 400 (400 MHz), and BRUKER AVANCE III HD 500 (500 MHz) instrument. All 
1H NMR spectra were consistent with the proposed structures. All proton shifts are provided in parts per million (ppm) downfield from the appropriate internal deuterated solvent peak or tetramethylsilane $(\delta)$ as the internal standard in deuterated solvent, and the coupling constants $(J)$ are in hertz $(\mathrm{Hz})$. The NMR data are reported as follows: chemical shift, multiplicity (s, singlet; d, doublet; t, triplet; q, quartet; spt, septet; m, multiplet; dd, doublet of doublets; td, triplet of doublets; ddd, doublet of doublet of doublets; and br s, broad singlet), coupling constants, and integration. The broad peaks of the protons of the hydroxyl and amino groups are not always indicated.

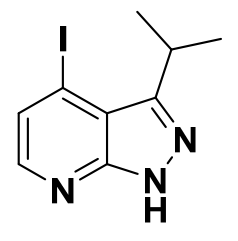

1

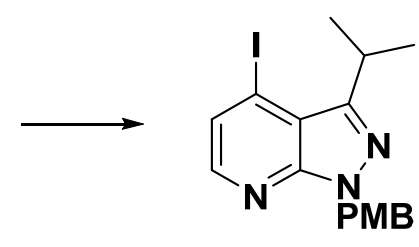

2

4-Iodo-3-isopropyl-1-(4-methoxybenzyl)-1H-pyrazolo[3,4-b]pyridine (2). To a solution of 1 $(10.0 \mathrm{~g}, 34.8 \mathrm{mmol})$ in $\mathrm{DMF}(100 \mathrm{~mL}), \mathrm{NaH}(50 \%, 2.0 \mathrm{~g}, 41.8 \mathrm{mmol})$ was added at $0^{\circ} \mathrm{C}$ and stirred for $10 \mathrm{~min}$ under nitrogen atmosphere. Then, $5.2 \mathrm{~mL}$ of $\mathrm{PMBCl}(38.3 \mathrm{mmol})$ was added to the reaction mixture at $0^{\circ} \mathrm{C}$. After being stirred for $10 \min$ at $0^{\circ} \mathrm{C}$, the reaction mixture was allowed to reach room temperature and then stirred for $2 \mathrm{~h}$. The reaction mixture was quenched with water and diluted with AcOEt. The organic phase was washed with brine, dried over anhydrous $\mathrm{MgSO}_{4}$, and concentrated in vacuo. The residue was purified using flash silica chromatography (Biotage ${ }^{\circledR}$ SNAP Ultra column, eluent, 6-60\% EtOAc in hexane) to obtain $12.8 \mathrm{~g}(91 \%)$ of $\mathbf{2}$ as a pale-yellow wax. UPLC-MS (ESI) $m / z=408.3[\mathrm{M}+\mathrm{H}]^{+}, t_{\mathrm{R}}=2.36 \mathrm{~min} .{ }^{1} \mathrm{H}$ NMR $\left(400 \mathrm{MHz}, \mathrm{CDCl}_{3}\right) \delta 1.43(\mathrm{~d}$, $J=6.8 \mathrm{~Hz}, 6 \mathrm{H}), 3.74$ (s, 3H), 3.89 (spt, $J=6.8 \mathrm{~Hz}, 1 \mathrm{H}), 5.58$ (s, 2H), 6.79-6.82 (m, 2H), 7.25-7.30 (m, 2H), $7.52(\mathrm{~d}, J=4.9 \mathrm{~Hz}, 1 \mathrm{H}), 8.00(\mathrm{~d}, J=4.9 \mathrm{~Hz}, 1 \mathrm{H})$. 


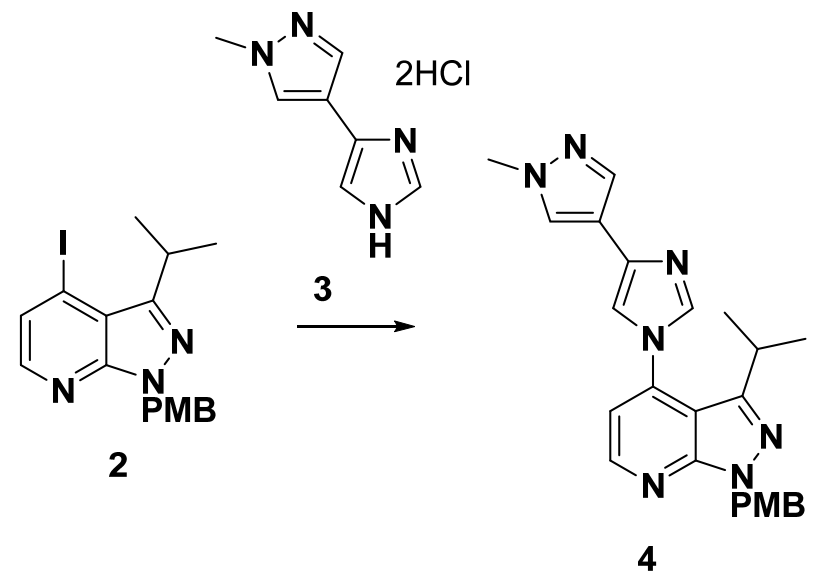

\section{3-Isopropyl-1-(4-methoxybenzyl)-4-(4-(1-methyl-1H-pyrazol-4-yl)-1H-imidazol-1-yl)-1H-}

pyrazolo[3,4-b]pyridine (4). The mixture of 2 (1.0 g, $2.46 \mathrm{mmol}), 3$ (652 $\mathrm{mg}, 2.95 \mathrm{mmol}), \mathrm{Cu}_{2} \mathrm{O}$ (10.5 mg, $0.074 \mathrm{mmol}$ ), 4,7-dimethoxy-1,10-phenanthroline (53.1 mg, $0.221 \mathrm{mmol}), \mathrm{Cs}_{2} \mathrm{CO}_{3}(2.4$ g, $7.37 \mathrm{mmol})$, PEG $(491 \mathrm{mg})$, and DMSO $(10 \mathrm{~mL})$ was stirred at $110^{\circ} \mathrm{C}$ for $24 \mathrm{~h}$ under nitrogen atmosphere. After cooling to room temperature, the reaction mixture was diluted with EtOAc and filtered through a celite pad. The celite pad was washed with EtOAc, and the filtrate was diluted with water, washed with brine, dried over $\mathrm{Na}_{2} \mathrm{SO}_{4}$, and concentrated in vacuo. The residue was purified using flash silica chromatography (Biotage ${ }^{\circledR}$ SNAP Ultra column, eluent, $12-100 \%$ EtOAc in hexane, and $0-20 \% \mathrm{MeOH}$ in EtOAc) to obtain $654 \mathrm{mg}(62 \%)$ of 4 as a pale-yellow amorphous powder. UPLC-MS (ESI) $\mathrm{m} / \mathrm{z}=428.2[\mathrm{M}+\mathrm{H}]^{+}, t_{\mathrm{R}}=1.60 \mathrm{~min} .{ }^{1} \mathrm{H}$ NMR $(400 \mathrm{MHz}$, $\left.\mathrm{CDCl}_{3}\right) \delta 1.19(\mathrm{~d}, J=6.6 \mathrm{~Hz}, 6 \mathrm{H}), 3.07(\mathrm{spt}, J=6.7 \mathrm{~Hz}, 1 \mathrm{H}), 3.78(\mathrm{~s}, 3 \mathrm{H}), 3.97(\mathrm{~s}, 3 \mathrm{H}), 5.66(\mathrm{~s}, 2 \mathrm{H})$, 6.82-6.86 (m, 2H), $7.01(\mathrm{~d}, J=5.1 \mathrm{~Hz}, 1 \mathrm{H}), 7.31$ (d, $J=1.5 \mathrm{~Hz}, 1 \mathrm{H}), 7.34-7.38(\mathrm{~m}, 2 \mathrm{H}), 7.77-7.78$ (m, 3H), $8.57(\mathrm{~d}, J=5.1 \mathrm{~Hz}, 1 \mathrm{H})$. 


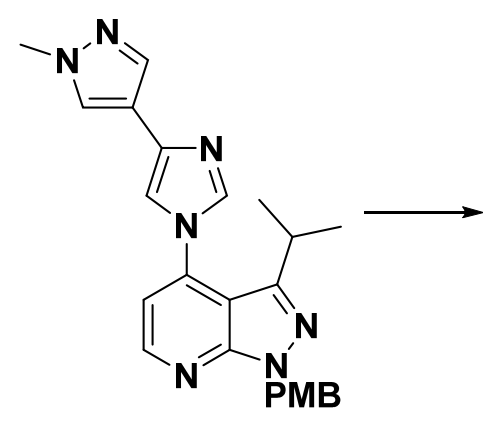

4

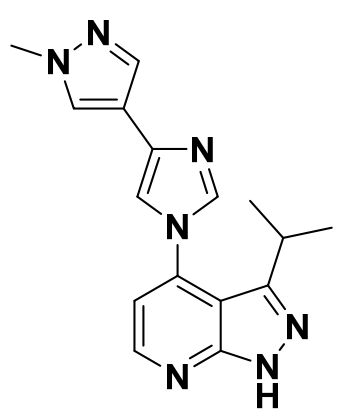

THS-975

\section{3-Isopropyl-4-(4-(1-methyl-1H-pyrazol-4-yl)-1H-imidazol-1-yl)-1H-pyrazolo[3,4-}

b]pyridine (THS-975). To a mixture of $4(600 \mathrm{mg}, 1.40 \mathrm{mmol})$ and anisole $(0.23 \mathrm{~mL}, 2.11 \mathrm{mmol})$, TFA ( $3 \mathrm{~mL})$ was added and stirred at reflux for $5 \mathrm{~h}$. After cooling to room temperature, the reaction mixture was concentrated in vacuo. The residue was purified using flash silica chromatography (Biotage ${ }^{\circledR}$ SNAP Ultra and Biotage ${ }^{\circledR}$ Sfär KP-Amino D columns, eluent, 0-20\% MeOH in EtOAc) to obtain $379 \mathrm{mg}(88 \%)$ of THS-975 as a pale-yellow powder. UPLC-MS (ESI) $\mathrm{m} / \mathrm{z}=308.2$ $[\mathrm{M}+\mathrm{H}]^{+}, t_{\mathrm{R}}=1.00 \mathrm{~min} . \mathrm{UPLC}$ purity $99.53 \% .{ }^{1} \mathrm{H}$ NMR $\left(400 \mathrm{MHz}, \mathrm{DMSO}-d_{6}\right) \delta 1.06(\mathrm{~d}, J=6.8 \mathrm{~Hz}$, 6H), 3.06-3.16 (m, 1H), $3.87(\mathrm{~s}, 3 \mathrm{H}), 7.23$ (d, J=4.9 Hz, 1H), 7.73 (d, J=0.6 Hz, 1H), 7.81 (d, $J=1.4 \mathrm{~Hz}, 1 \mathrm{H}), 7.96(\mathrm{~s}, 1 \mathrm{H}), 8.12$ (d, J=1.4 Hz, 1H), 8.59 (d, J=4.9 Hz, 1H), 13.67 (br s, 1H). HRMS calcd for $\mathrm{C}_{16} \mathrm{H}_{18} \mathrm{~N}_{7} 308.1624[\mathrm{M}+\mathrm{H}]^{+}$, found 308.1624 .

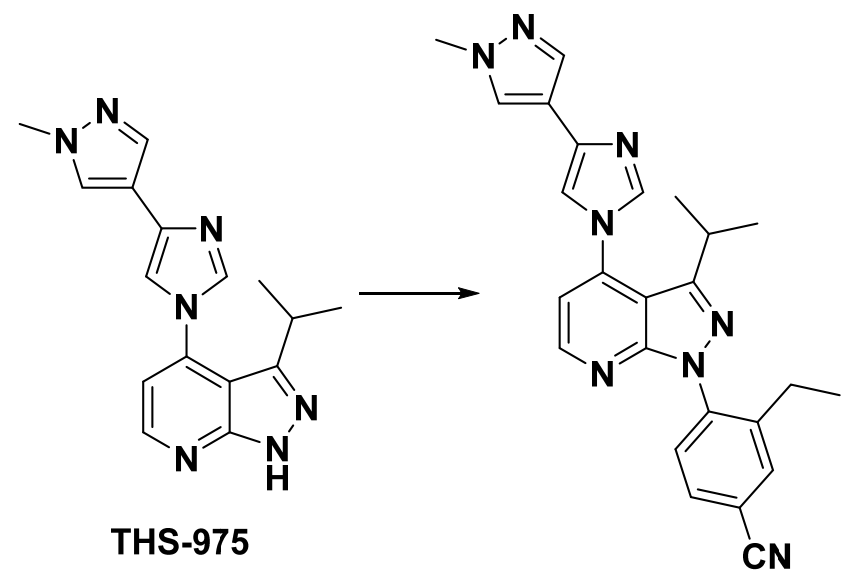

5 


\section{3-ethyl-4-(3-isopropyl-4-(4-(1-methyl-1H-pyrazol-4-yl)-1H-imidazol-1-yl)-1H-}

pyrazolo[3,4-b]pyridin-1-yl)benzonitrile (5). A mixture of THS-975 (100 mg, $0.33 \mathrm{mmol}), 3$ ethyl-4-fluorobenzonitrile (145.6 mg, $0.98 \mathrm{mmol}), \mathrm{Cs}_{2} \mathrm{CO}_{3}(127.2 \mathrm{mg}, 0.39 \mathrm{mmol})$, and DMF (1 $\mathrm{mL}$ ) was stirred at $120^{\circ} \mathrm{C}$ for $14 \mathrm{~h}$ under nitrogen atmosphere. After cooling to room temperature, the reaction mixture was diluted with EtOAc and water. The organic phase was washed with brine, dried over anhydrous $\mathrm{MgSO}_{4}$, and concentrated in vacuo. The residue was purified using flash silica chromatography (Biotage ${ }^{\circledR}$ SNAP Ultra column, eluent, 0-20\% MeOH in EtOAc and Biotage ${ }^{\circledR}$ Sfär KP-Amino D column, eluent, $12-100 \%$ EtOAc in hexane, and $0-20 \% \mathrm{MeOH}$ in EtOAc) to obtain $129 \mathrm{mg}(91 \%)$ of $\mathbf{5}$ as a white powder. UPLC-MS (ESI) $\mathrm{m} / \mathrm{z}=437.2[\mathrm{M}+\mathrm{H}]^{+}$, $t_{\mathrm{R}}=1.67 \mathrm{~min} .{ }^{1} \mathrm{H}$ NMR $\left(400 \mathrm{MHz}, \mathrm{CDCl}_{3}\right) \delta 1.15(\mathrm{t}, J=7.5 \mathrm{~Hz}, 3 \mathrm{H}), 1.25(\mathrm{~d}, J=6.8 \mathrm{~Hz}, 6 \mathrm{H}), 2.66$ (q, $J=7.6 \mathrm{~Hz}, 2 \mathrm{H}), 3.19$ (spt, $J=6.8 \mathrm{~Hz}, 1 \mathrm{H}), 3.99$ (s, 3H), 7.17 (d, $J=4.9 \mathrm{~Hz}, 1 \mathrm{H}), 7.39$ (d, $J=1.4$ Hz, 1H), 7.64-7.71 (m, 2H), 7.77 (d, J=1.4 Hz, 1H), 7.80-7.81 (m, 2H), 7.86 (d, J=1.3 Hz, 1H), $8.61(\mathrm{~d}, J=4.9 \mathrm{~Hz}, 1 \mathrm{H})$.

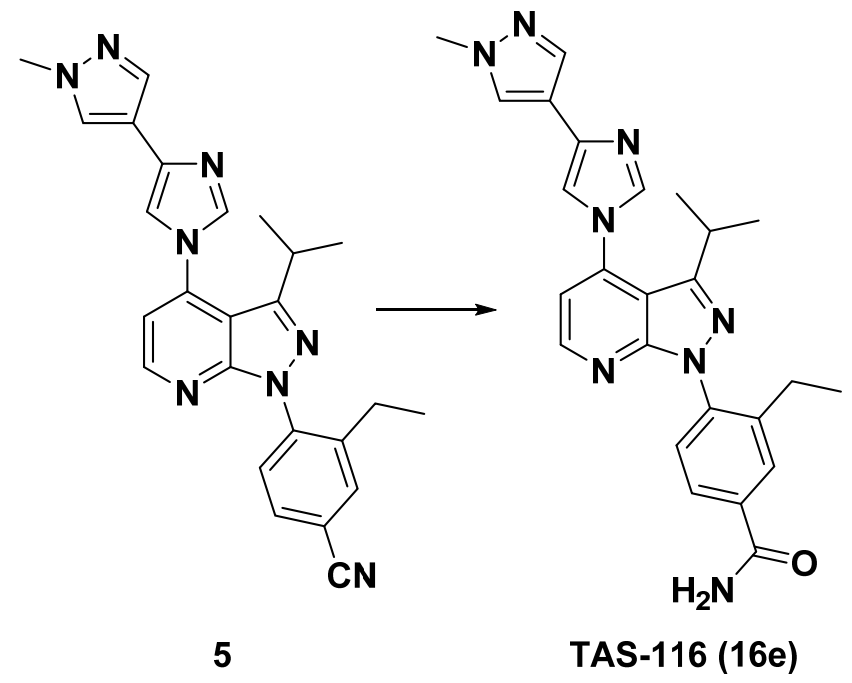

3-ethyl-4-(3-isopropyl-4-(4-(1-methyl-1H-pyrazol-4-yl)-1H-imidazol-1-yl)-1H-pyrazolo[3,4b]pyridin-1-yl)benzamide (TAS-116 (16e)). To a solution of 5 (100 mg, $0.23 \mathrm{mmol})$, DMSO (0.5 
$\mathrm{mL})$ and $\mathrm{EtOH}(1.0 \mathrm{~mL}), 4 \mathrm{M}-\mathrm{NaOH}$ aq. $(172 \mu \mathrm{L}, 0.69 \mathrm{mmol})$ and $30 \% \mathrm{H}_{2} \mathrm{O}_{2}$ aq. $(78 \mu \mathrm{L}, 0.69$ mmol) were added under ice cooling. After stirring for $30 \mathrm{~min}$ at $0^{\circ} \mathrm{C}$, the reaction mixture was allowed to warm to room temperature and then stirred for $2 \mathrm{~h}$. The reaction mixture was quenched with $10 \%$ aqueous $\mathrm{Na}_{2} \mathrm{~S}_{2} \mathrm{O}_{3}(1.0 \mathrm{~mL})$ under ice cooling and then diluted with $\mathrm{CHCl}_{3}$. The organic layer was separated, dried over $\mathrm{MgSO}_{4}$, and concentrated in vacuo. The residue was purified using flash silica chromatography (Biotage ${ }^{\circledR}$ SNAP Ultra column, eluent, 0-20\% MeOH in EtOAc) to obtain $73 \mathrm{mg}(70 \%)$ of TAS-116 (16e) as a white powder. UPLC-MS (ESI) $\mathrm{m} / \mathrm{z}=455.3[\mathrm{M}+\mathrm{H}]^{+}$, $t_{\mathrm{R}}=1.24 \mathrm{~min} . \mathrm{UPLC}$ purity $99.02 \% .{ }^{1} \mathrm{H}$ NMR $\left(400 \mathrm{MHz}, \mathrm{CDCl}_{3}\right) \delta 1.15(\mathrm{t}, J=7.6 \mathrm{~Hz}, 3 \mathrm{H}), 1.26(\mathrm{~d}$, $J=6.8 \mathrm{~Hz}, 6 \mathrm{H}), 2.63$ (q, J=7.6 Hz, 2H), 3.19 (spt, $J=6.8 \mathrm{~Hz}, 1 \mathrm{H}), 3.99$ (s, 3H), 5.68 (brs, 1H), 6.13 (brs, 1H), 7.14 (d, J=4.8 Hz, 1H), 7.39 (d, J=1.4 Hz, 1H), 7.59 (d, J=8.1 Hz, 1H), 7.78-7.81 (m, 3H), 7.87 (d, J=1.3 Hz, 1H), 7.97 (d, J=1.9 Hz, 1H), 8.60 (d, J=4.9 Hz, 1H). HRMS calcd for $\mathrm{C}_{25} \mathrm{H}_{27} \mathrm{~N}_{8} \mathrm{O} 455.2308[\mathrm{M}+\mathrm{H}]^{+}$, found 455.2311.

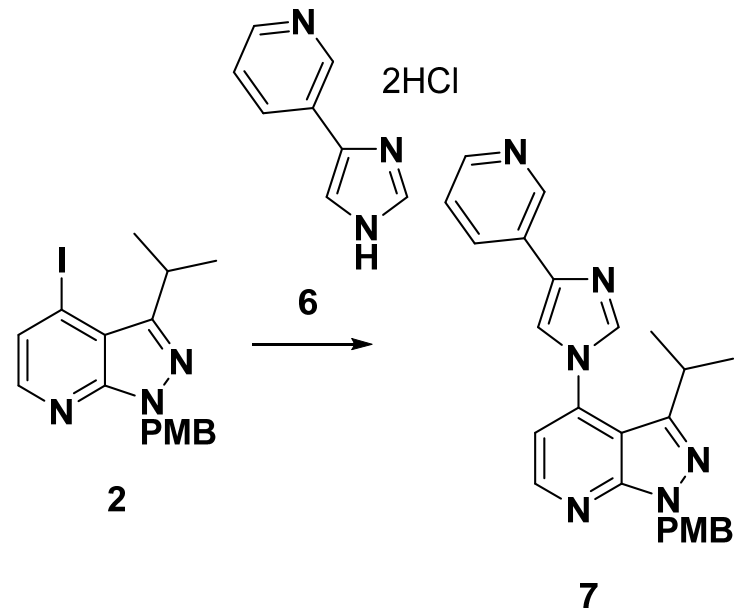

\section{3-Isopropyl-1-(4-methoxybenzyl)-4-(4-(pyridine-3-yl)-1H-imidazol-1-yl)-1H-pyrazolo[3,4-}

b]pyridine (7). The mixture of 2 (150 mg, $0.37 \mathrm{mmol}), 6$ (96 mg, $0.44 \mathrm{mmol}), \mathrm{Cu}_{2} \mathrm{O}(1.6 \mathrm{mg}$, $0.011 \mathrm{mmol}$ ), 4,7-dimethoxy-1,10-phenanthroline (8.0 mg, $0.033 \mathrm{mmol}), \mathrm{Cs}_{2} \mathrm{CO}_{3}$ (432 mg, 1.33 mmol), PEG (74 mg), and DMSO (1.5 mL) was stirred at $110^{\circ} \mathrm{C}$ for $24 \mathrm{~h}$ under nitrogen 
atmosphere. After cooling to room temperature, the reaction mixture was diluted with EtOAc and filtered through a celite pad. The celite pad was washed with EtOAc, and the filtrate was diluted with water, washed with brine, dried over $\mathrm{MgSO}_{4}$, and concentrated in vacuo. The residue was purified using flash silica chromatography (Biotage ${ }^{\circledR}$ SNAP Ultra column, eluent, $12-100 \%$ EtOAc in hexane, and $0-20 \% \mathrm{MeOH}$ in EtOAc) to obtain $86 \mathrm{mg}(55 \%)$ of 7 as a pale-yellow amorphous powder. UPLC-MS (ESI) $\mathrm{m} / \mathrm{z}=425.2[\mathrm{M}+\mathrm{H}]^{+}, t_{\mathrm{R}}=1.47 \mathrm{~min} .{ }^{1} \mathrm{H}$ NMR $(400 \mathrm{MHz}$, $\left.\mathrm{CDCl}_{3}\right) \delta 1.20(\mathrm{~d}, J=6.9 \mathrm{~Hz}, 6 \mathrm{H}), 3.05$ (spt, $\left.J=6.8 \mathrm{~Hz}, 1 \mathrm{H}\right), 3.78$ (s, 3H), 5.68 (s, 2H), 6.83-6.87 (m, 2H), 7.05 (d, $J=4.8 \mathrm{~Hz}, 1 \mathrm{H}), 7.36-7.40(\mathrm{~m}, 3 \mathrm{H}), 7.62$ (d, $J=1.4 \mathrm{~Hz}, 1 \mathrm{H}), 7.88$ (d, $J=1.3 \mathrm{~Hz}$ 1H), 8.19 (td, $J=7.9,1.9 \mathrm{~Hz}, 1 \mathrm{H}), 8.56-8.57(\mathrm{~m}, 1 \mathrm{H}), 8.61$ (d, $J=4.9 \mathrm{~Hz}, 1 \mathrm{H}), 9.08$ (d, $J=1.0 \mathrm{~Hz}$, $1 \mathrm{H})$.
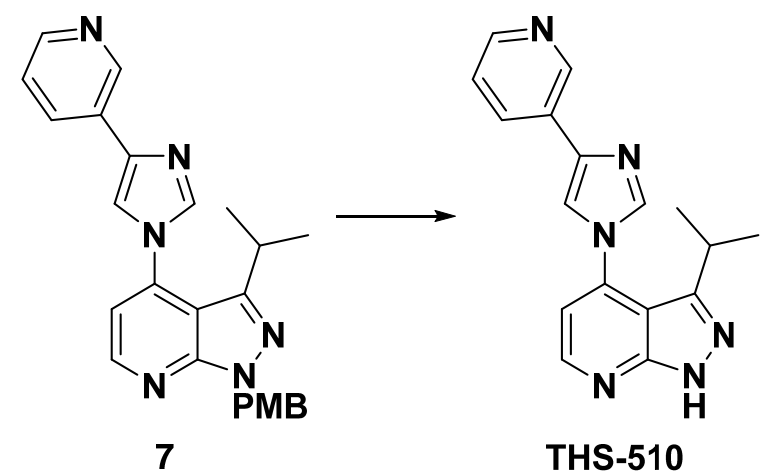

THS-510

\section{3-Isopropyl-4-(4-(pyridin-3-yl)-1H-imidazol-1-yl)-1H-pyrazolo[3,4-b]pyridine (THS-510).}

To a mixture of $7(84 \mathrm{mg}, 0.20 \mathrm{mmol})$ and anisole $(32 \mu \mathrm{L}, 0.30 \mathrm{mmol})$, TFA $(421 \mu \mathrm{L})$ was added and stirred at reflux for $4 \mathrm{~h}$. After cooling to room temperature, the reaction mixture was concentrated in vacuo. The residue was purified by flash silica chromatography (Biotage ${ }^{\circledR}$ SNAP Ultra column, eluent, $0-20 \% \mathrm{MeOH}$ in EtOAc) to obtain $39 \mathrm{mg}(65 \%)$ of THS-510 as a paleyellow amorphous powder. UPLC-MS (ESI) $\mathrm{m} / \mathrm{z}=305.1[\mathrm{M}+\mathrm{H}]^{+}, t_{\mathrm{R}}=0.90 \mathrm{~min}$. UPLC purity $\geq$ 99\%. ${ }^{1} \mathrm{H}$ NMR (500 MHz, DMSO-d6) $\delta 1.07$ (d, $J=6.9 \mathrm{~Hz}, 6 \mathrm{H}$ ), 3.10 (spt, $J=6.8 \mathrm{~Hz}, 1 \mathrm{H}$ ), 7.31 (d, 
$J=4.9 \mathrm{~Hz}, 1 \mathrm{H}), 7.46(\mathrm{dd}, J=7.7,5.0 \mathrm{~Hz}, 1 \mathrm{H}), 8.23(\mathrm{td}, J=8.0,1.9 \mathrm{~Hz}, 1 \mathrm{H}), 8.30(\mathrm{~d}, J=1.1 \mathrm{~Hz}, 1 \mathrm{H})$, $8.39(\mathrm{~d}, J=1.2 \mathrm{~Hz}, 1 \mathrm{H}), 8.48(\mathrm{dd}, J=4.7,1.1 \mathrm{~Hz}, 1 \mathrm{H}), 8.64(\mathrm{~d}, J=4.9 \mathrm{~Hz}, 1 \mathrm{H}), 9.11(\mathrm{~d}, J=1.4 \mathrm{~Hz}$ 1H), $13.73(\mathrm{~s}, 1 \mathrm{H})$. HRMS calcd for $\mathrm{C}_{17} \mathrm{H}_{17} \mathrm{~N}_{6} 305.1515[\mathrm{M}+\mathrm{H}]^{+}$, found 305.1512 .
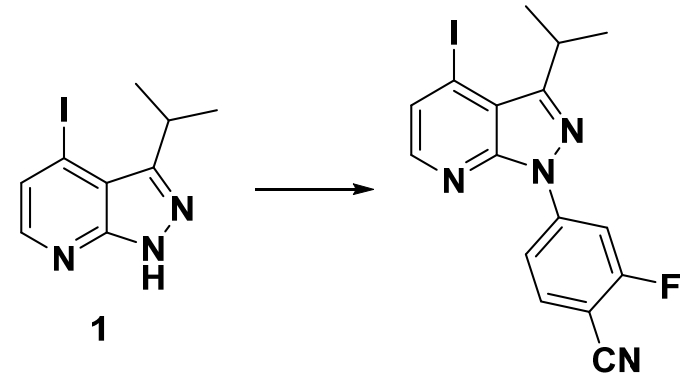

8

\section{2-Fluoro-4-(4-iodo-3-isopropyl-1H-pyrazolo[3,4-b]pyridin-1-yl)benzonitrile $\quad$ (8). To a} solution of $1(10.0 \mathrm{~g}, 34.8 \mathrm{mmol})$ in DMF $(100 \mathrm{~mL}), \mathrm{NaH}(50 \%, 1.84 \mathrm{~g}, 38.3 \mathrm{mmol})$ was added at $0^{\circ} \mathrm{C}$ under nitrogen atmosphere. After being stirred for $10 \mathrm{~min}$ at $0^{\circ} \mathrm{C}, 2,4$-difluoro-benzonitrile (5.33 $\mathrm{g}, 38.3 \mathrm{mmol})$ was added to the reaction mixture at the same temperature. Subsequently, the reaction mixture was heated and stirred at $60^{\circ} \mathrm{C}$ for $1 \mathrm{~h}$. Then, water was added to the mixture and then the mixture was stirred at room temperature for $1 \mathrm{~h}$. The resulting precipitate was collected by filtration. The precipitate was washed with water and dried under vacuum to obtain a mixture of $13.4 \mathrm{~g} \mathrm{(95 \% )}$ of $\mathbf{8}$ and its regioisomer as a white powder. The crude product was used for the next reaction without further purification.

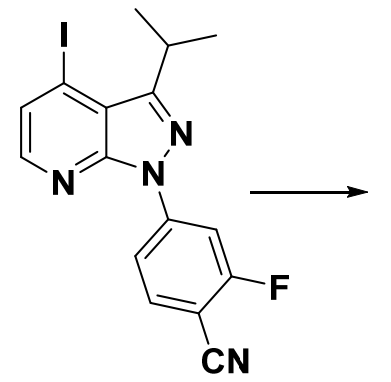

8

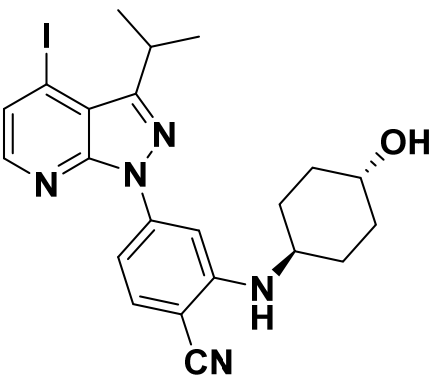

9 


\section{2-((trans-4-Hydroxycyclohexyl)amino)-4-(4-iodo-3-isopropyl-1H-pyrazolo[3,4-b]pyridin-1-}

yl)benzonitrile (9). The solution of 8 and its regioisomer (13.4 g, $33.1 \mathrm{mmol})$, trans-4aminocyclohexanol (4.19 g, $36.4 \mathrm{mmol})$, DIPEA (5.76 mL, $33.1 \mathrm{mmol})$, and DMSO (81 mL) was stirred at $125^{\circ} \mathrm{C}$ for $5 \mathrm{~h}$ under nitrogen atmosphere. Subsequently, the reaction was warmed to $150^{\circ} \mathrm{C}$ and stirred for $3 \mathrm{~h}$. After cooling to room temperature, water $(241 \mathrm{~mL})$ was added to the mixture and the mixture was stirred at room temperature for $2 \mathrm{~h}$. The resulting precipitate was collected by filtration. The precipitate was washed with water and dried under vacuum to obtain crude 9 as a brown amorphous solid. Crude 9 was purified using flash silica chromatography (Biotage ${ }^{\circledR}$ SNAP Ultra column, eluent, $12-100 \%$ EtOAc in hexane) to obtain $2.50 \mathrm{~g}(15 \%)$ of 9 as a pale-red powder. UPLC-MS (ESI) $m / z=501.9[\mathrm{M}+\mathrm{H}]^{+}, t_{\mathrm{R}}=2.40 \mathrm{~min} .{ }^{1} \mathrm{H}$ NMR $(400 \mathrm{MHz}$, DMSO-d 6$) \delta 1.26-1.46(\mathrm{~m}, 10 \mathrm{H}), 1.88-1.90(\mathrm{~m}, 2 \mathrm{H}), 2.00-2.02(\mathrm{~m}, 2 \mathrm{H}), 3.37-3.47(\mathrm{~m}, 2 \mathrm{H}), 3.90-$ $3.97(\mathrm{~m}, 1 \mathrm{H}), 4.59$ (br s, 1H), 5.83-5.86 (m, 1H), 7.58-7.63 (m, 2H), 7.88-7.92 (m, 2H), 8.20$8.23(\mathrm{~m}, 1 \mathrm{H})$.

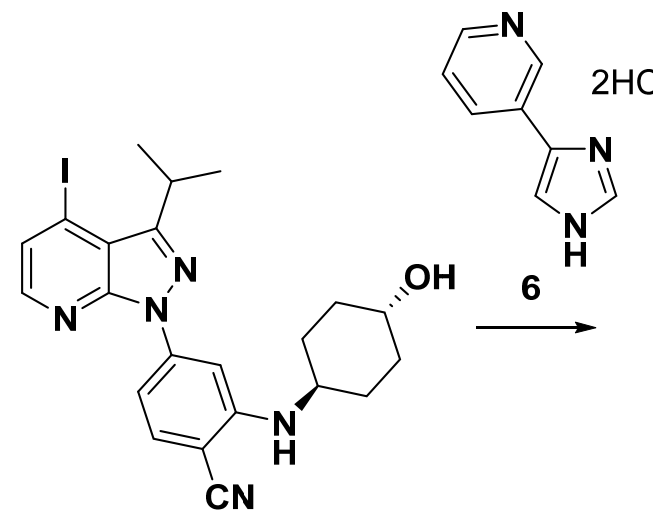

10

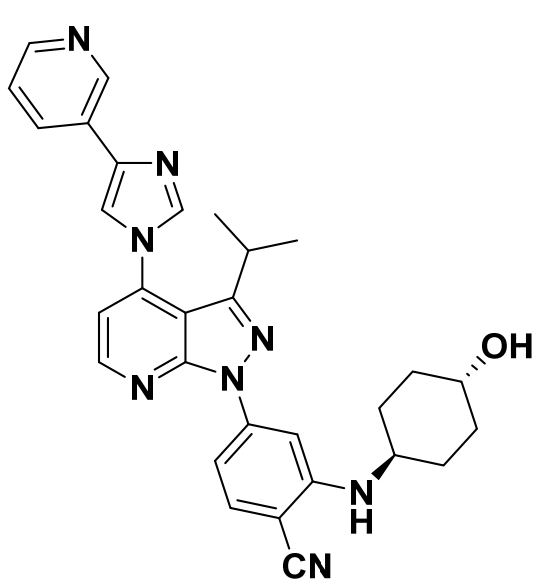

11

2-((trans-4-hydroxycyclohexyl)amino)-4-(3-isopropyl-4-(4-(pyridin-3-yl)-1H-imidazol-1-yl)$1 H$-pyrazolo[3,4-b]pyridin-1-yl)benzonitrile (11). To a mixture of 10 (50 mg, $0.10 \mathrm{mmol}), 6$ 
(26.1 mg, $0.12 \mathrm{mmol}$ ), $\mathrm{CuO}$ nanopowder (4.0 mg, $0.05 \mathrm{mmol}), \mathrm{K}_{2} \mathrm{CO}_{3}(41.4 \mathrm{mg}, 0.20 \mathrm{mmol}$ ), and DMF $(0.5 \mathrm{~mL})$ were added and stirred at $120^{\circ} \mathrm{C}$ for $20 \mathrm{~h}$ under nitrogen atmosphere. After cooling to room temperature, the reaction mixture was diluted with EtOAc and filtered through a celite pad. The celite pad was washed with EtOAc, and the filtrate was washed with brine, dried over $\mathrm{MgSO}_{4}$, and concentrated in vacuo. The residue was purified using flash silica chromatography (Biotage $^{\circledR}$ SNAP Ultra column; eluent, 12-100\% EtOAc in Hexane and then $0-20 \% \mathrm{MeOH}$ in EtOAc) to obtain $33 \mathrm{mg}(63 \%)$ of 11 as pale-yellow powder. UPLC-MS (ESI) $\mathrm{m} / \mathrm{z}=519.3[\mathrm{M}+\mathrm{H}]^{+}$, $t_{\mathrm{R}}=1.47 \mathrm{~min} .{ }^{1} \mathrm{H}$ NMR $\left(400 \mathrm{MHz}, \mathrm{CDCl}_{3}\right) \delta 1.26(\mathrm{~d}, J=6.8 \mathrm{~Hz}, 6 \mathrm{H}), 1.36-1.46(\mathrm{~m}, 2 \mathrm{H}), 1.49-1.58$ (m, 2H), 2.10-2.14 (m, 2H), 2.27-2.30 (m, 2H), 3.12 (spt, J=6.8 Hz, 1H), 3.50-3.55 (m, 1H), 3.75-3.81 (m, 1H), $4.55(\mathrm{~d}, J=7.4 \mathrm{~Hz}, 1 \mathrm{H}), 7.22$ (d, J=4.9 Hz, 1H), 7.41 (ddd, J=8.0, 4.9, 0.8 Hz, 1H), $7.54(\mathrm{~d}, J=8.5 \mathrm{~Hz}, 1 \mathrm{H}), 7.66(\mathrm{~d}, J=1.4 \mathrm{~Hz}, 1 \mathrm{H}), 7.75$ (dd, $J=8.6,1.9 \mathrm{~Hz}, 1 \mathrm{H}), 7.91(\mathrm{~d}, J=1.4$ Hz, 1H), 7.99 (d, J=1.9 Hz, 1H), 8.20-8.23 (m, 1H), 8.58 (dd, J=4.9, 1.6 Hz 1H), 8.72 (d, J=4.9 $\mathrm{Hz}, 1 \mathrm{H}), 9.09$ (dd, $J=2.2,0.8 \mathrm{~Hz}, 1 \mathrm{H})$.

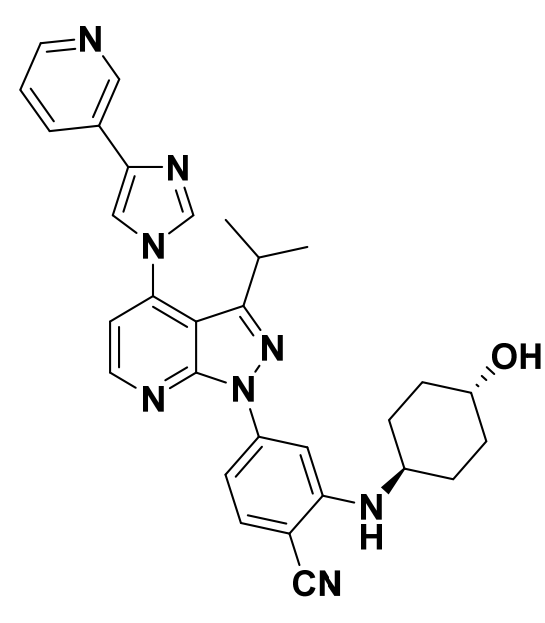

11

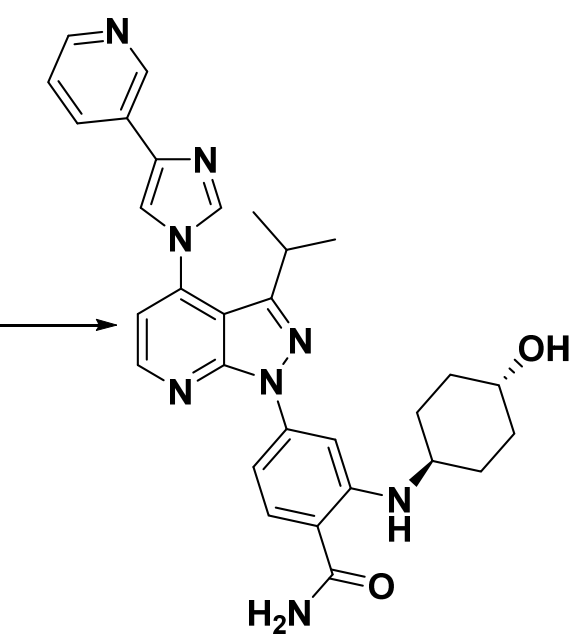

THS-762

2-((trans-4-hydroxycyclohexyl)amino)-4-(3-isopropyl-4-(4-(pyridin-3-yl)-1H-imidazol-1-yl)1H-pyrazolo[3,4-b]pyridin-1-yl)benzamide (THS-762). To a solution of 11 (25 mg, 0.048 
mmol), DMSO (0.13 mL), and EtOH $(0.25 \mathrm{~mL}), 4 \mathrm{M}-\mathrm{NaOH}$ aq. $(12.1 \mu \mathrm{L}, 0.048 \mathrm{mmol})$ and $30 \%$ $\mathrm{H}_{2} \mathrm{O}_{2}$ aq. $(16.4 \mu \mathrm{L}, 0.145 \mathrm{mmol})$ were added under ice cooling. After stirring for $1 \mathrm{~h}$ at $0^{\circ} \mathrm{C}$, the reaction mixture was quenched with $10 \%$ aqueous $\mathrm{Na}_{2} \mathrm{~S}_{2} \mathrm{O}_{3}(0.25 \mathrm{~mL})$ under ice cooling and then diluted with $\mathrm{CHCl}_{3}$. The organic layer was dried over $\mathrm{MgSO}_{4}$ and concentrated in vacuo. The residue was purified using flash silica chromatography (eluent, 0-20\% $\mathrm{MeOH}$ in EtOAc) to obtain $20 \mathrm{mg}(79 \%)$ of THS-762 as white powder. UPLC-MS (ESI) $\mathrm{m} / \mathrm{z}=537.3[\mathrm{M}+\mathrm{H}]^{+}, t_{\mathrm{R}}=1.19 \mathrm{~min}$. UPLC purity 98.15\%. ${ }^{1} \mathrm{H}$ NMR (400 MHz, DMSO-d6) $\delta 1.14(\mathrm{~d}, J=6.8 \mathrm{~Hz}, 6 \mathrm{H}), 1.24-1.40(\mathrm{~m}$, 4H), 1.87-1.91 (m, 2H), 2.10-2.12 (m, 2H), 3.20 (spt, $J=6.8 \mathrm{~Hz}, 1 \mathrm{H}), 3.49-3.55(\mathrm{~m}, 1 \mathrm{H}), 4.60(\mathrm{~d}$, $J=4.1 \mathrm{~Hz}, 1 \mathrm{H}), 7.17$ (brs, 1H), 7.42-7.48 (m, 2H), 7.52 (d, J=5.0 Hz, 1H), 7.78-7.81 (m, 2H), 7.86

(brs, $1 \mathrm{H}), 8.23$ (td, $J=8.0,1.9 \mathrm{~Hz}, 1 \mathrm{H}), 8.37$ (d, $J=1.1 \mathrm{~Hz}, 1 \mathrm{H}), 8.42$ (br s, $1 \mathrm{H}), 8.44$ (d, J=1.1 Hz, $1 \mathrm{H}), 8.49$ (dd, $J=4.8,1.5 \mathrm{~Hz}, 1 \mathrm{H}), 8.81(\mathrm{~d}, J=4.9 \mathrm{~Hz}, 1 \mathrm{H}), 9.12(\mathrm{~d}, J=1.6 \mathrm{~Hz}, 1 \mathrm{H})$. HRMS calcd for $\mathrm{C}_{30} \mathrm{H}_{33} \mathrm{~N}_{8} \mathrm{O}_{2} 537.2726[\mathrm{M}+\mathrm{H}]^{+}$, found 537.2726 .

\section{Purification of chemicals}

All the synthesized compounds have been checked the purities by using ultra-performance liquid chromatography-mass spectrometry (UPLC-MS). All solvents and reagents were obtained from commercial sources and were used as received. The UPLC-MS analysis was performed using

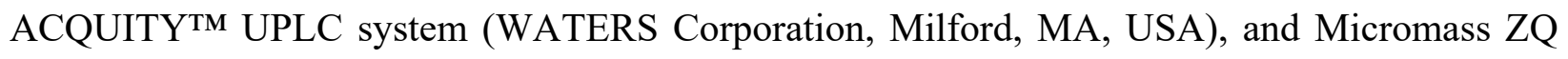
Mass Spectrometer (WATERS Corporation, Milford, MA, USA) equipped with electrospray ionization in the ESI positive mode. The column used was an Acquity UPLC ${ }^{\circledR}$ BEH C18-column $\left(2.1 \mathrm{~mm} \times 50 \mathrm{~mm}, 1.7 \mu \mathrm{m}\right.$, Waters Corporation) at $40^{\circ} \mathrm{C}$ with a flow rate of $0.5 \mathrm{~mL} / \mathrm{min}$. Mobile phase A was $0.5 \%$ formic acid in water. Mobile phase B was $0.5 \%$ formic acid in acetonitrile, 
which was increased linearly from $5 \%$ to $95 \%$ over $2 \mathrm{~min}, 95 \%$ to $98 \%$ over the next $1.4 \mathrm{~min}$, after which the column was equilibrated to $5 \%$ for $1.5 \mathrm{~min}$ and detected at $254 \mathrm{~nm}$. All the final test compounds were purified to $>95 \%$ chemical purity.

\section{Characterization of chemicals}

The proton nuclear magnetic resonance $\left({ }^{1} \mathrm{H}\right.$ NMR) spectra were recorded on a Varian Mercury400 (400 MHz), JEOL JNM-AL400 (400 MHz), BRUKER AVANCE NEO 400 (400 MHz) instrument. All the 1H NMR spectra were consistent with the proposed structures. All proton shifts are provided in parts per million (ppm) downfield from the appropriate internal deuterated solvent peak or tetramethylsilane $(\delta)$ as the internal standard in deuterated solvent, and the coupling constants $(\mathrm{J})$ are in hertz $(\mathrm{Hz})$. The NMR data are reported as follows: chemical shift, multiplicity (s, singlet; d, doublet; t, triplet; spt, septet; m, multiplet; dd, doublet of doublets; td, triplet of doublets; brs, broad singlet; and brd, broad doublet), coupling constants, and integration. The broad peaks of the protons of hydroxyl and amino groups are not always indicated.

\section{Characterization Data.}

\section{3-Ethyl-4-(3-isopropyl-4-(4-(1-methyl-1H-pyrazol-4-yl)-1H-imidazol-1-yl)-1H- pyrazolo[3,4-b]pyridin-1-yl)benzamide (TAS-116).}




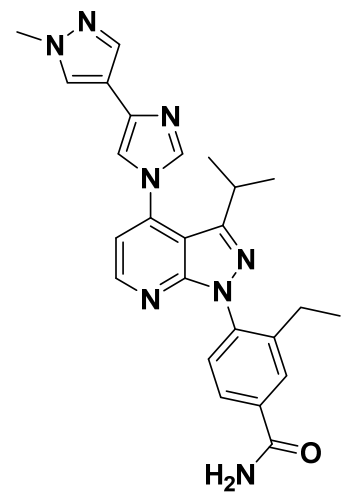

UPLC-MS (ESI) $\mathrm{m} / \mathrm{z}=454.8[\mathrm{M}+\mathrm{H}]^{+}, t_{\mathrm{R}}=1.19 \mathrm{~min}$. UPLC purity $99.65 \% .{ }^{1} \mathrm{H} \mathrm{NMR}(400 \mathrm{MHz}$, $\left.\mathrm{CDCl}_{3}\right) \delta 1.14(\mathrm{t}, J=7.5 \mathrm{~Hz}, 3 \mathrm{H}), 1.25(\mathrm{~d}, J=7.0 \mathrm{~Hz}, 6 \mathrm{H}), 2.62$ (q, $\left.J=7.3 \mathrm{~Hz}, 2 \mathrm{H}\right), 3.18$ (spt, $J=6.8$ Hz, 1H), 3.98 (s, 3H), 5.88 (brs, 1H), 6.22 (brs, 1H), 7.13 (d, J=5.1 Hz, 1H), 7.39 (d, J=1.1 Hz, 1H), $7.58(\mathrm{~d}, J=8.1 \mathrm{~Hz}, 1 \mathrm{H}), 7.78-7.81(\mathrm{~m}, 3 \mathrm{H}), 7.86(\mathrm{~d}, J=1.5 \mathrm{~Hz}, 1 \mathrm{H}), 7.96(\mathrm{~d}, J=1.8 \mathrm{~Hz}, 1 \mathrm{H})$, $8.59(\mathrm{~d}, J=4.7 \mathrm{~Hz}, 1 \mathrm{H})$. HRMS calcd for $\mathrm{C}_{25} \mathrm{H}_{27} \mathrm{~N}_{8} \mathrm{O} 455.2308[\mathrm{M}+\mathrm{H}]^{+}$, found 455.2311 .

\section{3-Isopropyl-4-(4-(pyridin-3-yl)-1H-imidazol-1-yl)-1H-pyrazolo[3,4-b]pyridine (THS-510).}

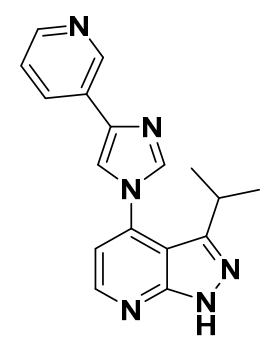

UPLC-MS (ESI) $\mathrm{m} / \mathrm{z}=304.7[\mathrm{M}+\mathrm{H}]+, t_{\mathrm{R}}=0.94 \mathrm{~min}$. UPLC purity $>99 \%$. 1H NMR $(400 \mathrm{MHz}$, DMSO-d6) $\delta 1.08$ (d, J=6.8 Hz, 6H), 3.11 (spt, $J=6.8 \mathrm{~Hz}, 1 \mathrm{H}), 7.31$ (d, J=4.9 Hz, 1H), 7.46 (dd, $J=4.8,7.8 \mathrm{~Hz}, 1 \mathrm{H}), 8.23(\mathrm{td}, J=1,9,8.0 \mathrm{~Hz}, 1 \mathrm{H}), 8.31(\mathrm{~d}, J=1.3 \mathrm{~Hz}, 1 \mathrm{H}), 8.39(\mathrm{~d}, J=1.3 \mathrm{~Hz}, 1 \mathrm{H})$, 8.49 (brd, $J=3.4 \mathrm{~Hz}, 1 \mathrm{H}), 8.65$ (d, J=4.9 Hz, 1H), 9.11 (brs, 1H), 13.73 (s, 1H). HRMS calcd for

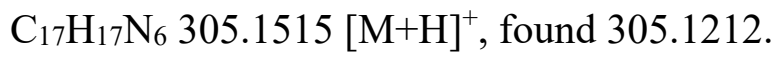


2-((trans-4-Hydroxycyclohexyl)amino)-4-(3-isopropyl-4-(4-(pyridin-3-yl)-1H-imidazol-1yl)-1H-pyrazolo[3,4-b]pyridin-1-yl)benzamide (THS-762).

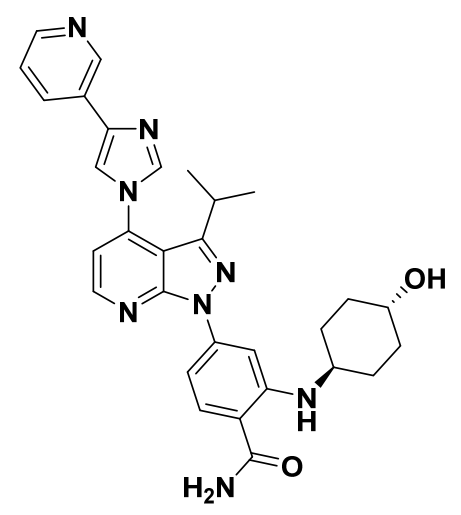

UPLC-MS (ESI) $\mathrm{m} / \mathrm{z}=537.2[\mathrm{M}+\mathrm{H}]^{+}, t_{\mathrm{R}}=1.15 \mathrm{~min}$. UPLC purity $99.09 \% .{ }^{1} \mathrm{H}$ NMR $(400 \mathrm{MHz}$, DMSO-d $)^{\prime} \delta 1.13(\mathrm{~d}, J=6.6 \mathrm{~Hz}, 6 \mathrm{H}), 1.21-1.42(\mathrm{~m}, 4 \mathrm{H}), 1.74-1.93(\mathrm{~m}, 2 \mathrm{H}), 2.02-2.16(\mathrm{~m}, 2 \mathrm{H})$, 3.18 (spt, $J=6.8 \mathrm{~Hz}, 1 \mathrm{H}), 3.25-3.36(\mathrm{~m}, 1 \mathrm{H}), 3.44-3.54$ (m, 1H), 4.58 (d, J=4.4 Hz, 1H), 7.16 (brs, 1H), 7.40-7.48 (m, 2H), 7.50 (d, J=4.8 Hz, 1H), 7.75-7.81 (m, 2H), 7.85 (brs, 1H), 8.22 (td, J=8.0, $1.9 \mathrm{~Hz}, 1 \mathrm{H}), 8.35-8.49(\mathrm{~m}, 4 \mathrm{H}), 8.79(\mathrm{~d}, J=5.1 \mathrm{~Hz}, 1 \mathrm{H}), 9.10(\mathrm{~s}, 1 \mathrm{H})$. HRMS calcd for $\mathrm{C}_{30} \mathrm{H}_{33} \mathrm{~N}_{8} \mathrm{O}_{2}$ $537.2726[\mathrm{M}+\mathrm{H}]^{+}$, found 537.2726 .

\section{UPLC analysis of chemicals}




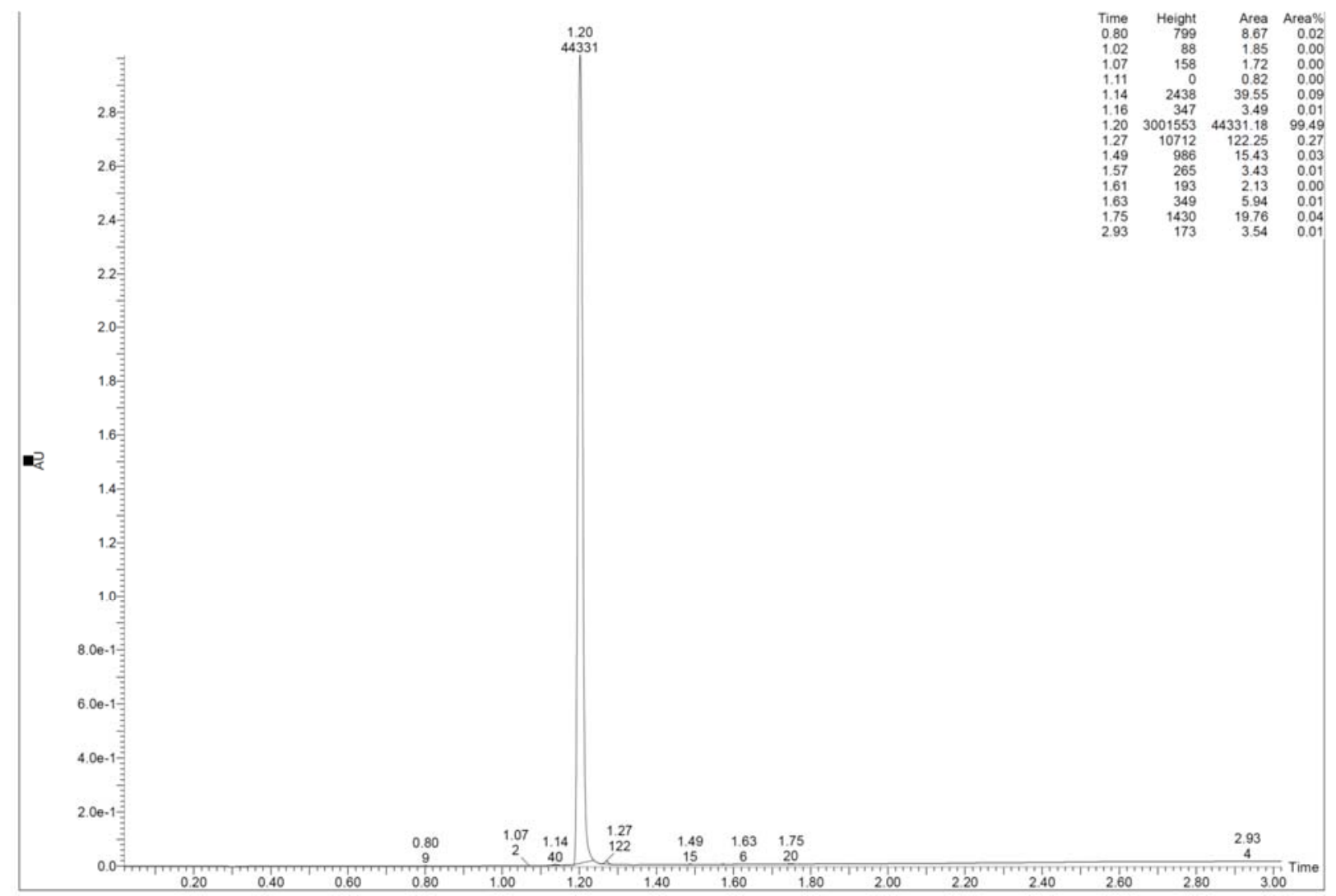

Figure S8. UPLC analysis of TAS-116. 


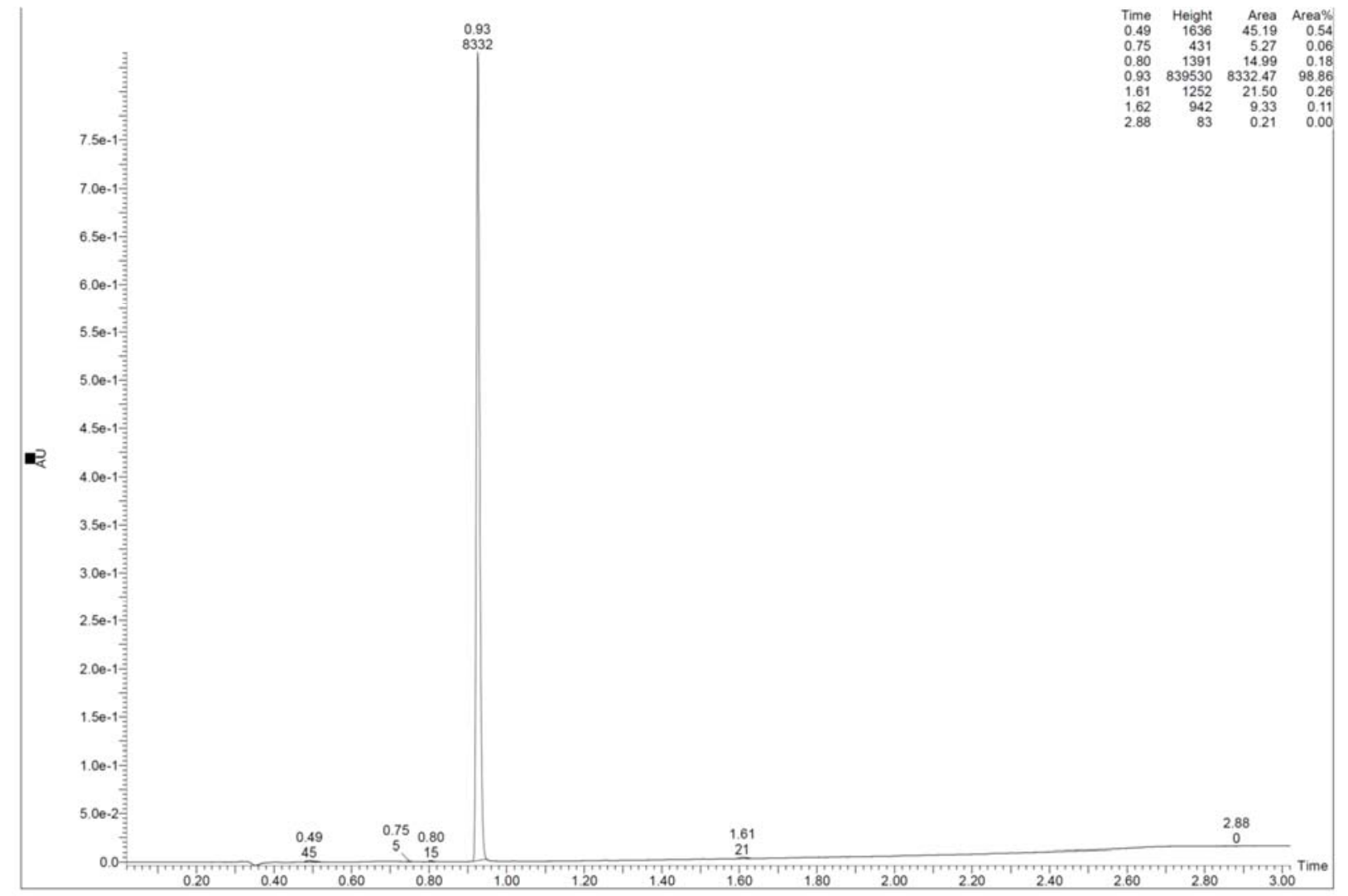

Figure S9. UPLC analysis of THS-510. 


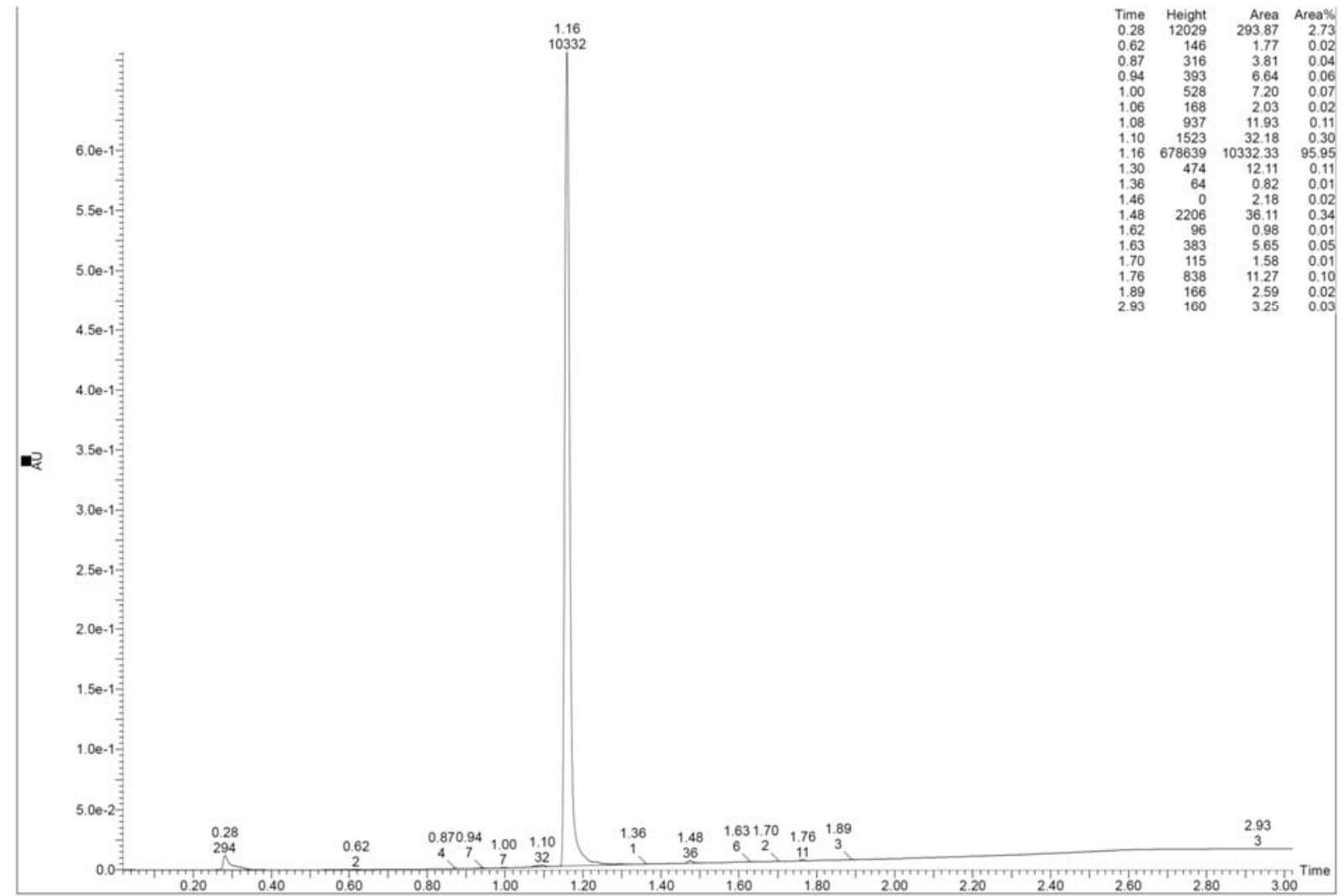

Figure S10. UPLC analysis of THS-762. 


\section{Reference}

1. Uno, T.; Kawai, Y.; Yamashita, S.; Oshiumi, H.; Yoshimura, C.; Mizutani, T.; Suzuki, T.; Chong, K. T.; Shigeno, K.; Ohkubo, M.; Kodama, Y.; Muraoka, H.; Funabashi, K.; Takahashi, K.; Ohkubo, S.; Kitade, M., Discovery of 3-Ethyl-4-(3-isopropyl-4-(4-(1-methyl-1 H-pyrazol-4-yl)-1 H-imidazol-1-yl)-1 H-pyrazolo[3,4- b]pyridin-1-yl)benzamide (TAS-116) as a potent, selective, and orally available HSP90 inhibitor. J. Med. Chem. 2019, 62, 531-551.

2. Kitade, M.; Yamashita, S.; Ohkubo, S., Novel bicyclic compound or salt thereof, WO2012093708A1, 2012.

3. Kitade, M.; Ohkubo, S.; Yoshimura, C.; Yamashita, S.; Oshiumi, H; Uno, T.; Kawai, Y., Azabicyclo compound and salt thereof, WO2011004610A1. 2011. 